\title{
The prevention of respiratory syncytial virus infection
}

\author{
L Bollani", M Pozzi \\ From XX National Congress of the Italian Society of Neonatology \\ Rome, Italy. 9-11 October 2014
}

Respiratory syncytial virus (RSV) is the most significant cause of acute respiratory tract infections in infants and young children worldwide. RSV accounts for approximately $70 \%$ of hospitalizations for bronchiolitis and $40 \%$ of pneumonia among infants $<1$ year of life.

RSV infection seems to be associated with recurrent wheezing during the first decade of life and impaired respiratory health-related quality of life in adults [1].

Universal prevention of RSV infection is based on environmental prophylaxis aimed at minimizing the spread of the virus good hand hygiene in the home, and limiting direct contact of high-risk children with other children and adults with respiratory tract infections. Exposure to tobacco smoke should be avoid in family with infants, breastfeeding should be encouraged.Pharmacological prophylaxis is based on the administration of palivizumab (Synagis ${ }^{\circledR}$, MedImmune) during the epidemic period to the children at risk [2].

Palivizumab is a humanized monoclonal antibody directed to an epitope in the A antigenic site of $\mathrm{F}$ protein of RSV. It is designed to provide passive immunity against RSV and thereby prevent or reduce the severity of RSV infection [2].

The aim of this work is to provide Italian neonatologists shared recommendations regarding palivizumab use in premature and other at-risk infants in the light of new emerging evidence.

The peak incidence of severe RSV disease occurs between 2 and 3 months of age. The risk of serious RSV illness is highest among preterm neonates, children with chronic lung disease, congenital heart disease $[3,4]$.

The children with the above mentioned clinical conditions, particularly in cases of hospitalization, are more likely to require admission to an intensive care unit and need mechanical ventilation. In addition they have high rates of re-hospitalization for lower respiratory tract infections [5,6].

Therefore, all these categories of infants are likely to benefit from prophylaxis, and have been included in the recommendations. Specific recommendations are provided according to gestational age at birth

RSV infections occur most frequently during the period between October-March.

According to this observation, prophylaxis with Palivizumab is indicated in this 5-6 months long seasonal window of RSV infection.

The duration of prophylaxis (up to one year or up to two years of life during the seasonal period) depends on the underlying condition.

Palivizumab is clinically effective; however, the cost is very high. In our opinion strict criteria for patient selection and reduced drug costs would improve the costeffectiveness of the prophylaxis [7].

\section{Published: 9 October 2014}

\section{References}

1. Backman K, Piippo-Savolainen E, Ollikainen H, Koskela H, Korppi M: Increased asthma risk and impaired quality of life after bronchiolitis or pneumonia in infancy. Pediatr Pulmonol 2014, 49:318-25.

2. The IMpact-RSV Study Group: Palivizumab, a humanized respiratory syncytial virus monoclonal antibody, reduces hospitalization from respiratory syncytial virus infection in high-risk infants. Pediatrics 1998, 102(3 Pt 1):531-7.

3. Committee on Infectious Diseases from the Academy of Pediatrics: policy statement: Modified Recommendations for use of Palivizumab for prevention of respiratory syncytial virus infections. In Pediatrics. Volume 124. American Academy of Pediatrics; 2009:(6):1694-1701.

4. Feltes TF, Cabalka AK, Meissner HC, Piazza FM, Carlin DA, Top FH Jr, Cardiac Study Group, et al: Palivizumab prophylaxis reduces hospitalization due to respiratory syncytial virus in congenital heart disease. J Pediatr 2003, 143:532-40.

5. Hall CB, Geoffrey A Weinberg, Aaron K Blumkin, et al: Respiratory syncytial virus associated hospitalization among children less than 24 months of age. Pediatrics 2013, 132:341-348. 
6. Committee on Infectious Diseases and Bronchiolitis Guidelines Committee: Updated guidance for palivizumab prophylaxis among infants and young children at increased risk of hospitalization for respiratory syncytial virus infection. Pediatrics 2014, 134:415-420.

7. Anabaka T, Nickerson JW, Rojas-Reyes MX, Rueda JD, Bacic Vrca V, Barsic B. Monoclonal antibody for reducing the risk of respiratory syncytial virus infection in children. Cochrane Database Syst Rev 2013, 4:CD006602.

doi:10.1186/1824-7288-40-S2-A35

Cite this article as: Bollani and Pozzi: The prevention of respiratory syncytial virus infection. Italian Journal of Pediatrics 2014 40(Suppl 2):A35.

Submit your next manuscript to BioMed Central and take full advantage of:

- Convenient online submission

- Thorough peer review

- No space constraints or color figure charges

- Immediate publication on acceptance

- Inclusion in PubMed, CAS, Scopus and Google Scholar

- Research which is freely available for redistribution

Submit your manuscript at www.biomedcentral.com/submit
C Biomed Central 